Special Issue on Migration and Globalization, Canadian Studies in Population

Vol. 29(1), 2002, pp. 1-30

\title{
Conceptualizing Transnational Community Formation: Migrants, Sojourners and Diasporas in a Globalized Era
}

\author{
W. Andy Knight \\ Department of Political Science \\ University of Alberta \\ Edmonton, Alberta
}

\begin{abstract}
Transnational communities have flourished in the globalized era, creating a Diaspora and sojourners that are unlike earlier waves of migrants. This paper first examines the main theories currently used to describe and explain international migration and find them wanting. Through an examination of two case studies of ethnic Japanese migrants (the Brazilian Nikkeijin and Peruvian Nikkei) who return to their homeland after living abroad for one or two generations, the paper goes on to demonstrate that the concept of 'international migrant' needs further theorizing to account for the impact of globalization and globalism. To this end, the author calls for the development of new theoretical understandings of the evolution of transnational community formation that would be multi-variate and robust enough to guide future public policy and research.
\end{abstract}

Key Words: International migration, globalization, sojourners, diaspora 
W. Andy Knight

\section{Résumé:}

A l'heure de la mondialisation, les communautés transnationales ont fleuri et donné naissance à une diaspora et à des personnes de passage qui différent des précédentes vagues de migrants. En premier lieu, cet article examine les principales theories selon lesquelles sont actuellement décrites et expliquées les migrations internationales et considère les failles de ces dernières. A travers deux études de cas de migrants japonais de deux ethnies (les Brésiliens Nikkeijin et les Péruviens Nikkei) qui retournent chez eux après avoir vécu à l'étranger pendant une ou deux générations, l'article démontre que le concept de «migrant international » demande une théorisation plus poussée qui tienne compte de l'impact de la mondialisation et du mondialisme. Pour aller dans ce sens, les auteurs appellent au développement de nouveaux moyens théoriques qui permettent de comprendre l'évolution de la formation des communautés transnationales. Des moyens qui devraient être multidiversifiés et suffisamment robustes pour guider la politique publique et la recherche à venir.

Mots clés: Migration internationale, mondialisation, personnes de passage, diaspora

\section{Introduction}

There has been a surge in analyses of international migration, diaspora politics, and ethnic and transnational community formation over the past decade or so within academic and policy circles, during what can be best labeled as a "transnational moment." [Keohane \& Nye, 1971] Journals such as Public Culture, Diaspora: A Journal of Transnational Studies, Global Governance: A Review of Multilateralism and International Organization, Population and Development Review, International Migration Review, Demography, and the revived Transitions are examples of some of the venues where this discourse is currently taking place among academics. Immigration and multi-cultural ministries in most major industrial countries are having to address these issues, and are especially concerned with illegal immigration (or queue-jumping) and undocumented migration in light of the fact that the in-flow of people into these countries is greater than the out-flow. [Edmonton Journal, May 27, 2001: p.B9 and United Nations, 1998]

The agendas of the United Nations, the European Union, the Commonwealth, La Francophonie, and other international bodies, reflect a major interest in transnational cultures, the politics of transnational and international migration, 
Conceptualizing Transnational Community Formation:

Migrants, Sojourners and Diasporas in a Globalized Era

and what James Clifford refers to as the "contact zones of nations, cultures and regions". ' [Clifford: p.283] In addition, conflicts and internecine violence have resulted in forced migration and the phenomenon of internally displaced persons. [Appadurai, 1999: 305-324] The situation is especially grave in Africa where, by the end of 2000 there were an estimated 3.6 million refugees. ${ }^{2}$ [UNHCR, 2001: 7]

This paper uses a multi-variate analysis to examine the phenomenon of international migration in the hope of shedding some conceptual light on what it has come to mean in the present globalized era. First, the main theoretical frameworks within which international migration has been analyzed in the past are succinctly presented. Each "theory" is found wanting in the sense that every one of them, in and of itself, cannot provide a necessary and sufficient explanation to account for the multifarious elements of trans-border mobilization. Secondly, two case studies are analyzed to see the extent to which some of the theories used to explain international migration hold. They also allow the reader to compare the pattern and variety of international migration among ethnic communities that are quite similar in terms of their history and experience, viz., Brazilian Nikkeijin and Peruvian Nikkei. Third, attention is then switched to examining the diaspora as one variant of international migration. A distinction is drawn between the traditional concept of diaspora and a revised concept of diaspora (as sojourners) in the age of globalization and globalism. The overall argument made in this paper is that at this particular juncture in our history, the patterns of international migration are changing. The changes are of such that there is a need to move towards a more comprehensive theorization of migration; one that critically and systematically analyzes and dissects the various elements of transnational community formation (from the more enduring to the transitory). The conclusion summarizes the findings and draw out some of the main questions which researchers in the future need to consider in developing a holistic theory of international migration.

However, before tackling the framework of analysis, it is important to understand why there has been such a verdant interest in the subject of international migration.

\section{Growing interest in the Study and Politics of International Migration}

Since the mid-1960s there has been a noticeable increase in the volume and level of international migration and ethnic mobilization. The number of international migrants went from 75 million in 1965 to 120 million in 1990. Indeed, close to half of the population growth in developed states was due to international migration. Specifically, in Europe that figure was even higher at 90\%. [United Nations, 1998: 166] This growth has been accelerated with the advent of what has been called the second wave of globalization. [Helleiner, 2001: 243-264] European countries, during this period, attracted significant numbers of immigrant workers from Africa, Asia, the Caribbean and the Middle East due in 
large part to the globalization of production. Canada and the United States also experienced a major influx of new immigrants from those areas. Even Japan, which is stereotypically considered a xenophobic society began to import migrant workers as well from poor countries in Asia and as far away as South America to address domestic labour shortages amidst a declining birth rate and aging population.

Most of the world's developed industrialized states have, as a result of this international migration, slowly become multi-ethnic societies, much to the chagrin of many within their populations. One should note that prior to the 1960s international migration was not a major concern for most governments. In fact only 13 per cent of Governments had expressed policies with respect to immigration. But by the mid-1990s, that situation changed dramatically. By then, 40 countries had implemented specific immigration policies to deal with what was perceived as a potential problem. [Ibid: 166] A cynic could argue that international migration might not have received as much attention if the net inmigration in developed countries did not threaten to upset the socio-economic and political equilibrium that exists in these states.

It was at the Cairo International Conference on Population and Development in 1994 that the subject of international migration was thrust near the top of the international agenda. ${ }^{3}$ Countries faced with either an out-flow or in-flow of their population began to recognize that international migration was an important aspect of social and economic development. ${ }^{4}$ Some periphery countries became concerned with the "brain drain", while developed country leaders were anxious to control the flow of immigrants coming into their states. The main concern for the latter was with undocumented migrants and the drain which excessive migration could have on their welfare systems. In addition, a number of scholars noted that migration was perhaps the most ubiquitous form of globalization. [Held, et. al, 1999: 283-84]

The advent of a complex web of interconnectedness (aided in large part by international telephone and cell-phone linkages, satellite television, fax machines, computerization, the 'information superhighway' and improvements to transportation technologies) has been the result of both globalization and globalism $^{5}$ and often means that our lives are increasingly shaped by events that occur, and decisions that are made, at a great distance from us. [Mittelman, 1997] This fact has changed the very parameters of political life and calls into question the categorical distinctions that were made in the past between, for example, diaspora and other migrant communities. Globalization and globalism processes have made it possible for many international migrants to develop multiple loyalties and identities. Communication and transportation advances have made it easier for diasporic and other migrant communities to keep in touch with others in the ancestral homeland or in other countries where individuals from those ethnic communities may be found. Electronic banking has facilitated the process of migrant remittances (estimated at $\$ 75$ billion globally in 1994) from the 'host' country to the homeland. Transnationalization of production and capital has allowed for stronger economic relations between the international migrants and their country of origin. 


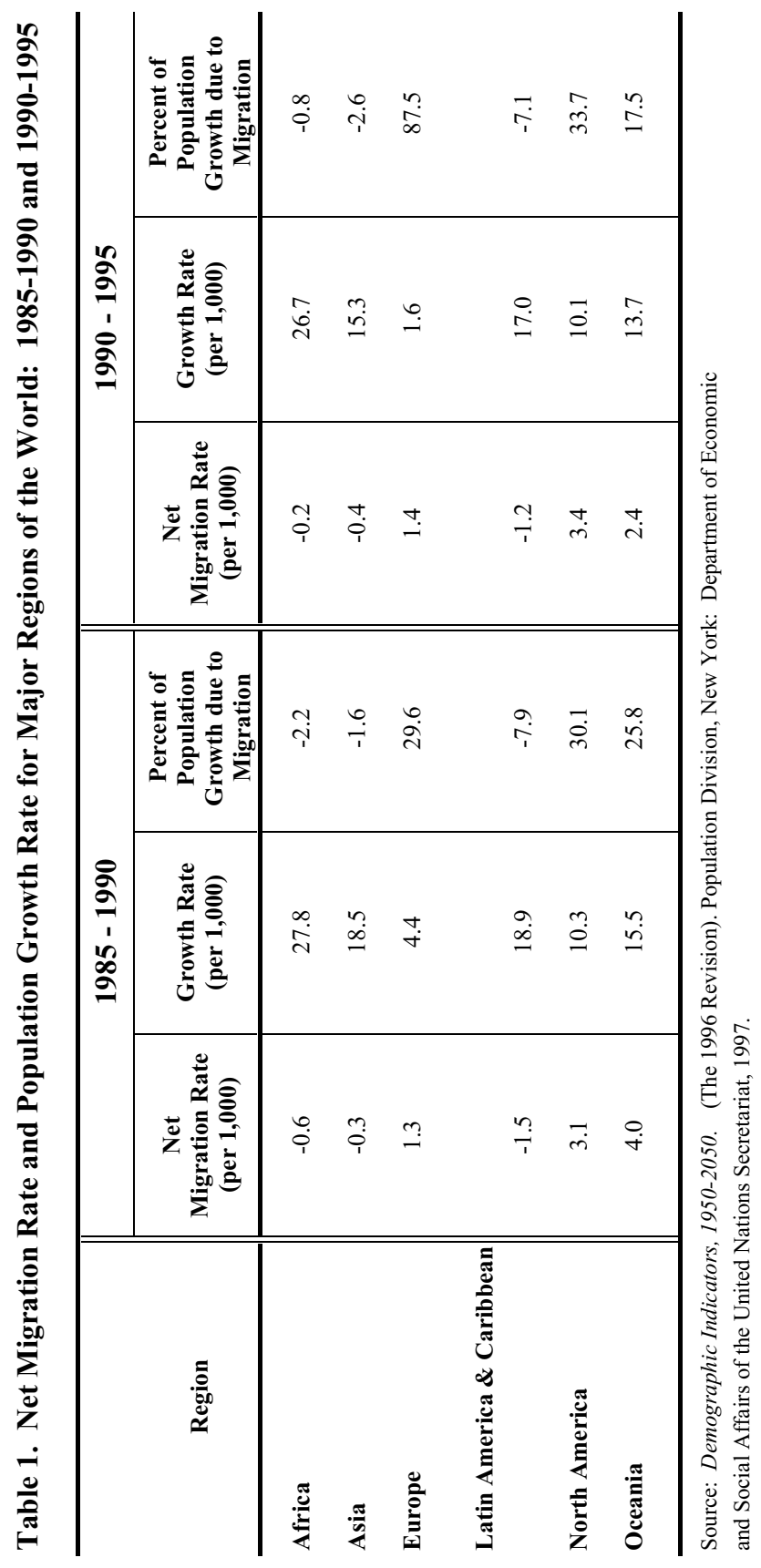


In effect, the nature of contemporary international migration patterns is affected by these changes. In many cases today, such migration can often be characterized as short-term or temporary sojourns in a host country, in contrast to earlier times when migrants left their homelands to settle abroad on a permanent basis. [Kritz \& Zlotnik, 1992: 1] Indeed, today people tend move back and forth between ancestral and host countries with regularity.

But perhaps the most important factor responsible for increasing the global level of consciousness about international migration issues was the noticeable change in the geo-political-strategic environment around 1989, with the fall of the Berlin Wall and the subsequent collapse of the Soviet Union. In particular, scholars and policy makers began to focus on the rise in intra-state conflicts and the concomitant increases in forced migration and displaced populations. Table 2 shows a marked increase in the number of refugees worldwide between 1985 and 1990. The total number of refugees worldwide went from 8.2 million in 1981 to 10.5 million in 1985 and then to 14.9 million in 1990 . It seemed to have leveled off by 1995 with the total hovering around 14.5 million and there was a slight decrease in early 1996 at 13.2 million. The significant increases in refugee flows was directly related to a number of natural disasters and major civil conflicts, particularly in Africa, the Balkans and some parts of Asia. ${ }^{6}$

Finally, particularly since the collapse of the bi-polar world, there has been an increased focus among academics and policy makers on issues of ethnicity and migration. John Rex notes that since 1989 the whole notion of "ethnicity" has been in "ill-repute". ' [Rex, 1997: 269] Some observers have noted that since that time, migrant ethnic minorities have been the focus of suspicion and hostility in a number of countries. ${ }^{8}$ [Abu-Laban, 1997] The increase in ethnic immigration has led to a backlash in countries like Germany, Switzerland and France. Some citizens in those countries see the influx of distant or 'alien' cultures as upsetting the equilibrium that has prevailed in their societies. Regardless of the reason, the phenomenon of international migration in the globalized era has become important for policymakers and academics alike. It has certainly raised a number of questions about the boundedness of states and forced us to reconsider some of the theories that have been used to explain it.

\section{Theoretical Explanations of International Migration}

Several explanatory frameworks have been used to explain this surge in international migration. Among them are: macro neo-classical economic theory; micro neo-classical economic theory; new economics of migration theory; dual labour market theory; world systems theory; and network theory. Yet, as noted earlier this phenomenon is still very much under-theorized. Existing explanations for international migration vary with the type of migration being analyzed and whether the researcher is focusing on migrants as individuals or on migration as a macro-level phenomenon. There is also a difference in the explanation depending on whether one is focusing on the processes that generate such migration or on those that sustain it. 


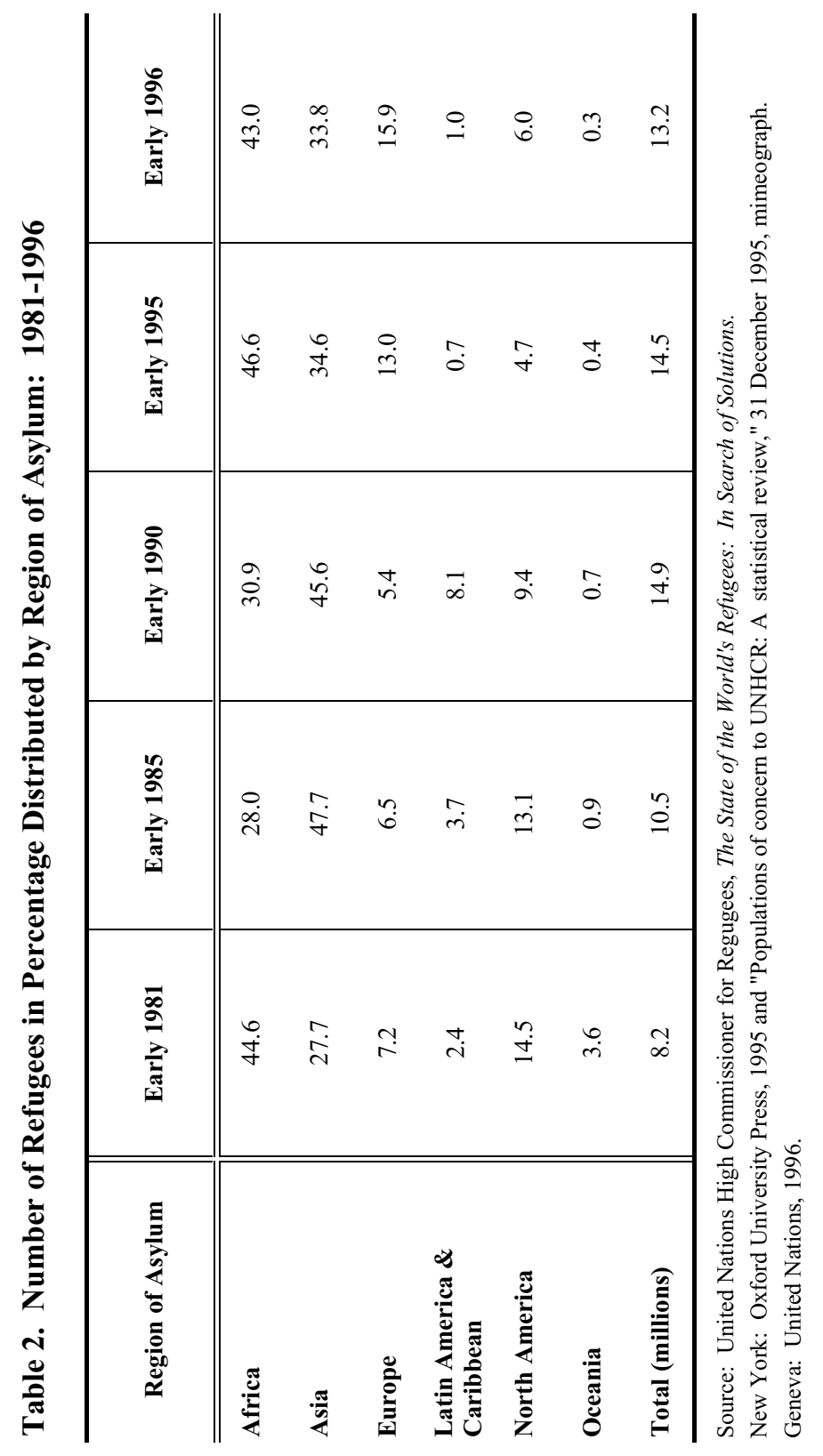


Proponents of neo-classical economic theory who analyze the issue of international migration from a macro level perspective argue that international migration is largely the result of workers who are moving in search of higher wages. In other words, the focus is on the international movement of economically active individuals. Thus, international migration is spurred on, according to this position, by differences in wage rates across countries. International migration of labour is largely demand-driven, according to this position. We can expect, then, increases in international migration when governments or particular industries or companies create various incentives for recruitment of workers from other countries, or when governments dismantle barriers to the free circulation of labour. The problem with this position, however, is that it tends to assume a homogeneity of skills between countries of origin and countries of destination. This assumption would lead one to believe that labour is more or less interchangeable and that full employment is maintained in both country of origin and country of destination during the migration period. Of course, those ideal conditions are seldom obtained in the real world. Hence it should not come as a surprise that the macro model of neoclassical theory is a poor (or insufficient) predictor of international migration patterns and effects.

Neo-classical economists who analyze this issue from a micro perspective tend to view international migration as stemming from international differentials in both earning and employment rates. They start from the premise that countries with a large endowment of labour relative to capital tend to have a low equilibrium market wage, whereas countries with a limited labour endowment relative to capital tend to have high market wages. The wage difference, according to this view, is the catalyst that entices workers from low-wage countries to move to high-wage ones. As the supply of labour decreases and wages rise in the country of origin and the supply of labour increases and wages fall in the country of destination, a new equilibrium is created in which wage differences reflect only the cost of migration. It is at that point that international migration will slow down or stop altogether. [Sjaastad, 1962: 80-93; Harris \& Todaro, 1970: 126-42]

Indeed, these microeconomic-level neo-classical theorists explain that there is a distinct pattern of migration amongst highly skilled workers and non-skilled workers. This could explain, in part, why individuals living in the same country might display different proclivities to migration. [Todaro, 1976] Regardless, there are certain human capital characteristics that will likely increase the flow of immigration into a "receiving" country, according to this position. The level of an individual's education, experience, training or language skill may determine if that individual is allowed to enter the labour market of a receiving country. Lack of employment or proper remuneration prospects may be the main factor in an individual's decision to migrate to a country where prospects are better. So human capital factors play a role in the selectivity of international migration, according to this position.

Also from the micro level, neo-classical economists argue that levels of migration are simply a matter of cost-benefit analyses/calculations made by 
Conceptualizing Transnational Community Formation: Migrants, Sojourners and Diasporas in a Globalized Era

rational individuals. When applying this explanation to actual case studies, the benefits of migration are measured against the net returns (i.e. the difference between expected earnings in the host country and expected earnings in the country of origin) at the individual level. Of course, it is not always possible to decipher how precisely those "expected earnings" are derived. And, it has to be taken into account that governments' macro economic policies could assist in inducing certain individuals to migrate. Correspondingly, such policies can also be constructed to discourage migration or control the levels of immigration. ${ }^{9}$ Basically, according to this position, increases in the levels of international migration occur when the cost of migration is lowered and decreases in such migration is evident when the cost of migration is raised. ${ }^{10}$ [Massey et. al, 1994: 699-751] The main problem with the micro-model of neo-classical theory is that it has not been tested rigorously in actual case studies of international migration.

The obvious limitations of both macro- and micro-level neo-classical theories sparked a paradigmatic shift towards alternative explanations of the international migration phenomenon. The so-called 'new economics of migration' explanation is focused at the micro-level. However, instead of making the assumption that decisions about migration are made simply by rational individuals acting on their own, this position holds that the decision to migrate (or not) is made by families, households or specific communities intent on maximizing expected income and minimizing any risks to their economic well-being. "From this perspective, sending certain family members to work in another country where wages and employment conditions are largely independent of local economic conditions is a form of insurance against the deterioration of the latter." [United Nations, 1998: 142] The remittances that are sent back home to the families, households or communities are then used to improve the economic lot of those individuals who remain and to raise their standard of living.

The implication of the new economics of migration theory is that international migration can indeed occur even when there are no obvious wage differentials between the country of origin and the country of destination. It also explains, in part, the trend of 'return migration', which is dealt with in the case studies below. Migrants who have done well for themselves in the country of destination, may decide to return home and use their gains to start up local businesses in the country of origin, or to buy property, houses, livestock, cars, etc., as status enhancers. The basic problem with this approach is that it does not sufficiently account for the impact globalization, and globalism, has had on international migration. Also, it does not fully explain why many educated international migrants choose to work in low-status, low wage jobs in the country of destination.

The dual labour market theory tries to fill this gap by positing that international migration results from a permanent demand for foreign labour in developed countries. [Piore, 1979] In these countries, because of the prevalence of high status, high paying position, finding local labour for low-status, low paying jobs might be difficult, particularly if those jobs do not offer prospect for upward mobility. Increasing wages at the bottom of the occupational hierarchy 
would cause pressure to increase wages at the upper level of that hierarchy. To avoid this, governments and businesses may decide to import foreign workers who are willing to work for the low wages and to fill those low status positions. These international migrants, usually from low-income countries, are generally individuals who presumably care little about upward mobility within the country of destination. Instead, they are content to earn the income from these low wage jobs because that income may be several times greater than the average wage in their home country. However, the dual labour market theory is insufficient in explaining the "push" factors that cause individuals to want to leave their home country for these low-status, low-wage jobs abroad.

Push and pull factors are better explained by world systems theorists who posit that international migration is directly linked to the structure of a world market that has been expanding exponentially since the sixteenth century. [Wallerstein, 1974] The capitalist expansion from Europe (the core) to areas in the periphery (and formerly non-capitalists societies) has resulted in the creation of a mobile population (generally from the South to the North). Thus international migration, according to this historical-structural model, merely follows the economic and political organization of a globally expanding capitalist market. The penetration of this capitalist market into the developing regions of the world is thus seen as a catalyst that drives international migration as the international flow of labour simply follows the international flow of goods and capital. This is especially the case between colonial powers and their former colonies, since the links between them are a by-product of the capitalist penetration of the periphery by the core countries. The problem with this position is its over-reliance on structural explanations to the exclusion of agency explanations. Also, it completely ignores the fact that there is now considerable south-south migration.

It is widely acknowledged today that international migration flows are not sufficiently explained by rational actor decision-making models or by economic factors that simply push migrants out of the sending country and pull them to the receiving country. Castles \& Miller, 1993: 21-22] Consideration has to be given to other factors that may provide alternate explanations of this phenomenon. For instance, economic theories of international migration are not sufficient to explain the migration that takes place because of political and religious persecution. Neither can structural theories fully explain the migration that occurs when individuals decide to move to a better climate for health reasons, or when they move simply for adventure, or when they move because of marriage or ethnic/family/community networks. Contrary to the position taken by economistic proponents of rational choice, it is evident that international migration is not always voluntary or a matter of choice. [Lee, 1966: 45-47] In other cases, international migration is facilitated by established family/community/ethnic networks in both the country of origin and the country of destination.

According to network theory, migrant networks "are sets of interpersonal ties that connect migrants, former migrants, and non-migrants in origin and destination areas through ties of kinship, friendship and shared community 
Conceptualizing Transnational Community Formation: Migrants, Sojourners and Diasporas in a Globalized Era

origin." [Massey, et. al, 1997: 264] There is sufficient evidence to show that some migrants rely on family members who are already established in the country of destination to obtain for them employment, accommodation and other forms of support during an initial period of adaptation in the country of destination. The way in which such networks increase the level of international migration is through the lowering of cost and risks of movement and the increase in expected net returns of migration. In a sense, network connections are a form of social capital upon which individuals draw in order to gain access to foreign employment and opportunities. International migration is therefore seen, according to this position, as a "self-sustaining diffusion process" which, once started, tends to expand over time as international migration becomes increasingly institutionalized through the said networks. [Bagchi, 2001: 9-31] Governments on the receiving end of international migration may reinforce these migrant networks through the development of immigration policies that give members of these networks certain special rights (e.g. the reunification of immigrants and their family members).

Migrant networks may also play a role in underground immigration markets. Particularly when a receiving government has developed policies designed to limit the flow of immigrants or to bar them from entry, migrant networks may work to assist potential immigrants in gaining access to that country. This can be done legally (e.g. arranged marriages between the migrant and a local from the host country) or illegally (e.g. via counterfeit documents and work visas or surreptitious smuggling of migrants across borders). Some migrant networks take on the role of humanitarian groups that provide counseling, legal and/or services, shelter, and protection from law enforcement authorities. But migrant network explanations are also limited by the very fact that they are conditional on the whims and fancies of particular state/society complexes either in the home country or the country of destination.

Indeed, all of the above explanatory frameworks have their limitations. They cannot account for all cases of international migration. Neither can they always explain particular types of, and specific trends in, international migration. Perhaps by examining the different categories of international migrants we may be able to arrive at a more holistic explanation for the phenomenon. In doing so, we will also be able to identify and understand some of the political/legal factors (at both the national and international levels) that could limit, facilitate or force international migration.

\section{Characterizing International Migrants}

Table 3 provides a breakdown of the possible categories of international migrants. There are essentially seven categories of international migrants. The first constitutes individuals who have migrated to another country in order to further their education and receive some form of specialized training usually not obtainable in their home country. Foreign students are generally admitted to the country of destination with a specific visa to follow a particular programme of 
Table 3

Possible Categories of International Migrants

\begin{tabular}{|c|c|}
\hline Migrants Admitted for Education and Training & $\begin{array}{l}\text { Foreign Students } \\
\text { Foreign Trainees } \\
\text { Dependents of above }\end{array}$ \\
\hline 1. Migrants Admitted for Employment & $\begin{array}{l}\text { Seasonal Migrant Workers } \\
\text { Project-tied Migrant Workers } \\
\text { Contract Migrant Workers } \\
\text { Temporary Migrant Workers } \\
\text { Dependents of the above }\end{array}$ \\
\hline 2. Migrants for Family Reunification & $\begin{array}{l}\text { Immediate Relatives } \\
\text { Marriage }\end{array}$ \\
\hline Migrants for Settlement & $\begin{array}{l}\text { Employment-based } \\
\text { Family-based } \\
\text { Ancestry-based } \\
\text { Treaty/Agreement-based } \\
\text { Retirees who are not a burden } \\
\text { to the State of Destination }\end{array}$ \\
\hline 3. Migrants Admitted for Humanitarian Reasons & $\begin{array}{l}\text { Convention Refugees } \\
\text { Resettled Refugees } \\
\text { Displaced Persons } \\
\text { Asylum Seekers } \\
\text { Temporary Protection }\end{array}$ \\
\hline 4. Diaspora & $\begin{array}{l}\text { Traditional } \\
\text { Non-Traditional }\end{array}$ \\
\hline 5. Undocumented Migrants & \\
\hline
\end{tabular}

Drawn from Box \#1 -

"Definitions of different categories of migrating foreigners," in Economic and Social Affairs, World Population Monitoring 1997: International Migration and Development .

New York: United Nations, 1998, p. 7. 
Conceptualizing Transnational Community Formation: Migrants, Sojourners and Diasporas in a Globalized Era

study for a specified period (usually one year at a time). Once that period is over, the visa expires and a new one would have to be obtained. In some countries, foreign students may be allowed to work. In which case, they would be granted a work visa for a specified time indicating the conditions under which the work is allowed. Similarly, foreign trainees can be admitted to a foreign country in order to acquire on-the-job skills. A visa would be granted, in such cases, for a specified period allowing those individuals to work within the specific institution that provides this training. Immediate relatives (spouse or dependent children) of foreign students or foreign trainees are usually allowed to stay in the receiving country for the duration of time that the particular migrant remains there.

The second category of international migrants is individuals who have been admitted to a foreign country for the explicit purpose of pursuing some economic activity/labour, which receives remuneration from within the receiving country. There are at least four sub-categories of these migrant workers: seasonal migrant workers; project-tied migrant workers; contract migrant workers; and temporary migrant workers. As the term implies, seasonal migrant workers are hired to perform work that depends on seasonal conditions (e.g. tobacco workers and fruit pickers in Ontario, Canada). Many of these individuals work in quite squalid conditions over a three to six-month period and then return to their homes, having accumulating much of the remuneration to be used to better themselves and family back home. Migrant workers who are admitted by a receiving country to work on a specified project must leave the country once the project has been completed. In most cases, the employer makes an arrangement with the state to employ these project-tied migrant workers is therefore responsible for ensuring that the migrants leaves the country once the project is carried out. Related to the above are contract migrant workers. Instead of being tied to a particular project, these migrants are issued a contract by the foreign country that sets limits on the period of employment and on the specific job being held. During the employment period, the contract migrant worker is not allowed to change jobs. Once the contract has been fulfilled, the migrant worker is expected to leave the receiving country before another contract can be issued. Temporary migrant workers may be admitted to a foreign country to work for a limited time in a specific occupation. They are allowed to change employers and have their work visa renewed without necessarily having to leave the country of employment. In all of the above cases, dependents of foreign migrant workers are allowed to accompany them.

The third category of international migrants constitute those foreigners who are granted admittance to a receiving country because they are either engaged or married to citizens of that country or to 'landed' immigrants (i.e. permanent residents who are not yet citizens). This category may also include other immediate family members who have applied to be reunited with an individual citizen or landed immigrant of the receiving country. The process of granting admittance is not always automatic as evidence of the relationship must be verified and the family member in the receiving state must also demonstrate that relative being brought into the country will not be a burden on the state. 
The fourth category refers to migrants who are granted permission to stay in the receiving country for a lengthy period or for an unspecified amount of time. In such cases, these migrants for settlement may be employment-based, i.e. selected for long term settlement because of particular qualifications or skills, which the receiving country may require. Some of these migrants may be candidates for long-term settlement because of family ties with citizens or landed immigrants in the receiving country. Others may be admitted because of their ancestral (historical/ethnic) link and may be granted citizenship in the receiving country in very short order. Then there are those migrants with the right to free establishment. By that is meant individuals who have the right to enter, reside and work in a state other then their own due to an agreement or treaty that has been concluded between the receiving and sending states. Finally, under 'migrants for settlement' are foreigners who have reached retirement age and who may be admitted to a receiving country under the condition that they do not become a burden on the state. Generally these individuals are allowed to be accompanied by their spouses.

The fifth category of international migrants is those foreigners who are admitted to a receiving country for humanitarian reasons. Refugees, asylum seekers, and individuals requiring temporary protection fall into this category. Refugees are "persons who, owing to a well-founded fear of persecution for reason of race, religion, nationality, membership of a particular social or political opinion, are outside of their country of nationality and are unable or, owing to such fear, are unwilling to avail themselves of the protection of that country." [United Nations, 1998: 7] It is important to make the legal distinction between Convention refugees - i.e. those refugees who are granted open-ended permission to stay in the country of asylum and resettlement refugees - i.e. those refugees who are admitted to another country for resettlement. Asylum seekers are individuals who file an application for asylum in a country other than their own and remain in the status of asylum seeker until their application is considered by the country willing to receive them. Some countries are willing to give open-ended but temporary protected status to individuals who are outside their home country but who cannot return because their lives are in danger. Other individuals may be in refugee-like situations but do not legally meet the United Nations 1951 Convention criteria of a refugee. In most cases, these individuals are afforded the same protection as refugees and may be admitted to a receiving country for humanitarian reasons.

The sixth category of international migrants is characterized by the term diaspora. The term diaspora is generally used to describe any population that is considered transnational or "deterritorialized" (i.e., which has originated in a country other than the one in which it currently resides and whose socioeconomic and political networks transcend state borders). Almost every minority group these days tend to consider itself a diaspora without giving much thought to the meaning of the word. This has resulted in an over-use and mis-use of the term. ${ }^{12}$ As Steven Vertovec notes, the term diaspora has "become a loose reference conflating such categories as immigrants, guest-workers, ethnic and 'racial' minorities, refugees, expatriates and travelers" and this has in effect "threatened the term's descriptive usefulness." [Vertovec, 1997: 277] 
Conceptualizing Transnational Community Formation: Migrants, Sojourners and Diasporas in a Globalized Era

However, I make the distinction between the traditional meaning of diaspora and the more contemporary and evolved concept. Initially the term diaspora was used exclusively in reference to the traumatic experience of Jews who were forced to leave their historical homeland, after the destruction of the second Temple in $70 \mathrm{AD}$, and were dispersed across the globe. [Encyclopaedia Judaica, 1971: 8-19; The Blackwell Companion to Jewish Culture, 1989: 167-69] The connotation of the concept of diaspora was therefore a negative one linked to displacement, victimization, alienation and loss. [Elazar, 1986: 212-257] Another important feature of this social form is its longing to return to its homeland. In the case of the Jews, it was not possible to return to their 'homeland' until the right political conditions were obtained. ${ }^{13}$

That term 'diaspora' was appropriated and applied to any people who have, more or less, been forced out of their homeland as a result of being conquered or persecuted. In other words, it has come to refer to the de-territorialization of a people as a result of forced displacement, victimization, alienation and loss (e.g. Greeks and Armenians). [Vertovec, 1997: 278-79] Today, the concept has come to embrace peoples of all nationalities and stripes who find themselves uprooted for both political and sometimes economic reasons. In essence, the contemporary usage of the term is generally in reference to a particular social form -- one that consists of an identifiable ethnic group that has been forced to live in a country or state that is not its ancestral home but has nevertheless been able to maintain some form of social bond despite being dispersed.

That social bond is usually the result of special historical and/or geographical ties that keep the diaspora together in either a national or transnational community. The construction of that community would most likely not be possible without reference to some ethnic myth, a common historical experience, a religious conviction or some tie to a specific geographic place. In most cases, the diaspora is able to develop networks of exchange and communication that connect the ancestral home with the new place of settlement. The tie to the homeland is generally strong for a couple of related reasons. First, there is usually a strong desire to return home when the political, economic or social conditions are right. Second, because the diaspora tends to hold on to its ethnicity or 'difference', it may be unwilling or unable to fit into the host society. Feelings of alienation and exclusion in the host country can therefore feed the desire to go back to the country of origin.

Because of the strong ties to the ancestral home, diasporas are more often than not involved as collective actors in bringing issues of the homeland to the attention of the host country government. We are all familiar with the strong Jewish and Irish lobbies in the United States, for instance. In some cases, these lobby groups are transnational because the diaspora may be dispersed to a number of countries. Globalization has facilitated the political actions of these trans-state groups. Appadurai notes, for instance, the Sikhs whose diaspora communities can be found in many countries, including the United States, Canada and the United Kingdom. [Appadurai, 1990: 301-02] 
The final category refers to a residual category of international migrants who fall outside of the domain of legal migration. Yet, the term "undocumented migrant" is preferable to "illegal migrant" in this case because of the normative connotation and generality of the latter term. [United Nations, 1998: 97] Due to its clandestine nature and the problems of procuring information on this category of international migrants, it would be difficult to determine the actual number of undocumented migrants. But the limited information that does exist on this class of migrants indicates an exponential increase in its numbers. Most of the developed states are very concerned with undocumented migration as public opinion in these states express resentment towards these individuals, "who are believed to be compromising the native population's economic and social welfare..." [Ibid: 97] Clearly, undocumented migration has become even more salient in the present globalized era. Governments have developed a number of policies ranging from tacit facilitation ${ }^{14}$ and amnesties to deportations as a means of dealing with this so-called problem in international migration.

The analysis of the above seven categories of international migration should help researchers make conceptual distinctions between the variants of this transborder phenomenon. It is hoped that such conceptual distinction will lead to the development of a more coherent and holistic theory of international migration. The case studies below also play a role in this theory building. First, the case of the Brazilian Nikkeijin will be examined for evidence of the nature and character of this particular international 'return migration'. Then the analysis will switch to the Peruvian Nikkei for evidence of the development of a transnational community formation. Finally, the evolved concept of contemporary diaspora communities will be examined in order to understand the character of the politics of a specific genre of international migrants during the current globalized era.

\section{The Case of the Brazilian Nikkeijin}

The case of the Brazilian Nikkeijin (individuals of Japanese origin who made their homes in Brazil) is an example of the sojourner mentality, which can be found among some international migrants. Japanese settlers first arrived on Brazilian shores around 1908. They were mostly Japanese farmers trying to escape impoverished conditions in rural Japan and willing to work on Brazilian coffee plantations until they made sufficient money to live comfortably in their ancestral home. Thus, from the beginning, these early migrants had every intention of returning home.

Recently (since the later 1980s), however, many of the Brazilian Nikkeijin (usually sons and daughters of Japanese who immigrated to Brazil) have begun to return to Japan as unskilled 'foreign workers'. The number of these Nikkeijin who are now living in Japan is approximately 220,000 and that number continues to grow slightly despite the noticeable downturn in the Japanese economy. ${ }^{15}$ [Tsuda, 1999: 10] What is interesting about this case is that the majority of these Brazilian Nikkeijin expect to work in Japan for only a number 
Conceptualizing Transnational Community Formation: Migrants, Sojourners and Diasporas in a Globalized Era

of years and then plan to return to Brazil. Despite the fact that they tend to come from middle-class socioeconomic backgrounds, with very good educational backgrounds, the Nikkeijin settle for unskilled, lower-end jobs while they are in Japan. They are usually given the label of dekasegi, i.e. temporary migrant worker. The primary motivation for taking on these jobs is simply to earn monies that can be remitted to their families' bank accounts back home in Brazil.

Between $60 \%$ to $80 \%$ of the Brazilian Nikkeijin name economic reasons as their primary motive for leaving Brazil. There is clearly a significant wage differential between Brazil and Japan. In fact, middle class Brazilian Nikkeijin who migrate to Japan and are occupied as unskilled 'dekasegi' workers in that country can earn as much as ten times the salary they can make in Brazil. This, more than anything else, was the main factor for most Nikkeijin who decided to migrate to Japan. [Ibid: 2-5] The saving which these individuals can make as a result of the high wages in Japan are then remitted back to family in Brazil and can be as high as four to five times the average yearly income they would have made if they had stayed in Brazil. What explains these large income disparities? One reason has to do with the fundamental economic imbalances in the international division of labor. But this is compounded by the unequal distribution of wealth and productive capacity between developed and developing states. Another reason has to do with the high value of the Japanese Yen, particularly during the 1980 s, which greatly increased the international value of Japanese wages. During that same period, there was a prolonged economic recession accompanied by hyperinflation in Brazil that resulted in a decline in real incomes and purchasing power in that country.

The prolonged economic recession in Brazil posed a major threat to the relatively high socio-economic status of Nikkeijin living in that country. This provided another reason for them to migrate. The Nikkeijin were not willing to see their socio-economic status in Brazil downgraded. Employment in Japan provided them with a means of maintaining that status and, in some cases, improving upon it. Indeed, "...they wished to use their sojourn in Japan to improve or maintain their standard of living in Brazil by purchasing homes, cars, and 'luxury' items such as video and audio equipment, home appliances, TVs, and other electronic goods -- things that they had come to expect in their lives, but which had become increasingly unaffordable." [Ibid: 4] In other words, their motivation for leaving Brazil was not because of an absolute level of economic deprivation but due to "relative deprivation", which is "based on a discrepancy between expectations and economic reality." [Ibid]

Added to the above reasons are the economic pull factors such as the great demand for migrant workers in Japan. The acute shortage of unskilled labour in Japan coincided with the economic downturn in Brazil. By the mid to late 1980 s, the Japanese birth rate had experienced continuous decline and it was evident that the Japanese population was also aging rapidly. [Cornelius: 1994: 378] These factors, combined with the inability of Japanese companies to draw on rural labor or Japanese youth to work in low-end jobs, meant that Japan's domestic work force was unable to meet the increasing demand for unskilled 
labor during a period of economic boom. Mechanization, automation and other labour-saving devices (robots, etc.) were tried, as an attempt to address the labour shortage, but had more or less reached their limits in Japan. The Japanese government therefore needed an influx of unskilled workers to help ease the labour shortage as well as to offset the huge welfare costs that were accumulating. Thus, these circumstances provided a "pull" factor for Brazilian Nekkeijin who took advantage of this window of opportunity to improve their economic lot. [Table 4]

Thus, it can be argued that Brazilian Nikkeijin who migrate to Japan conduct a rational cost benefit analysis in making their decision. But those decisions are aided by definite "push-pull" economic factors as well. Yet, the above microeconomic and macro-economic analyses cannot provide a full explanation of this migration flow. Although economic factors may have been the initial impetus for this particular migration, other reasons have come into play in this case. Among them are historical, ethnic and socio-cultural variables that act as transnational connection channels between the sending and receiving countries. Examining such variable is important because of the obvious lack of economic linkage that existed between Brazil and Japan prior to this wave of Nekkeijin migration out of Brazil into Japan.

Transnational ethnic ties between Japanese-Brazilians and Japan quite obviously played a major role in sustaining the migration flow to Japan (what some have called 'a return migration'). [Gmelch, 1980: 135-59] Ethnic consciousness is something that can be perpetuated over generations. Ethnic bonds are primordial, recurrent and largely inexplicable. They can have a certain nonrational and overpoweringly emotive quality to them. The Japanese who left Japan for Brazil at the turn of the last century have managed to maintain their kinship network in the host country. They not only passed on the myths, symbols and narratives to their children and grandchildren, they also in most cases maintained contact with relatives who remained in Japan. Indeed, the Brazilian Nikkeijin have been able to sustain their Japanese ethnic traits by remaining culturally distinct from Brazilians. [Reichl, 1995: 31-62] This very strong consciousness of transnational ethnic connections to their ancestral homeland perhaps best explains why the Brazilian Nikkeijin opted for migration to Japan as opposed to going to the United States or Europe when similar job opportunities were available in those countries. It also explains why the Japanese government, well known for its xenophobia, would revise its immigration laws and restrictionist policies to accommodate these return migrants. ${ }^{16}$ By bringing in individuals of Japanese descent and race to fill a real need in the work force, the government of Japan was able to maintain its cherished goal of keeping Japan as ethnically homogenous as possible.

Clearly, cultural similarities between the Brazilian Nikkeijin and the local Japanese made it easier for the former to be accepted into the Japanese work force. ${ }^{17}$ They were the most acceptable of all foreigners to the Japanese people. In addition, most of the Nikkeijin had at least some familiarity with the Japanese language (even if they did not speak the language fluently) which helped to facilitate their acclimatization into the Japanese society. Indeed, the 
Conceptualizing Transnational Community Formation: Migrants, Sojourners and Diasporas in a Globalized Era

initial wave of Brazilian Nikkeijin into Japan was made easier as many Nikkeijin were able to get their Japanese relatives to sponsor them and to assist them in finding employment. Thus, one can argue that the awareness of this strong it was ultimately a strong transnational ethnic affiliation between the Brazilian Nikkeijin and local Japanese contributed to the so-called return migration (ancestral migration) and may in fact have been just as important as the economic push-pull factors. [Sellek, 1996: 246-69]

As the economic benefits of this migration become evident to remaining Nikkeijin in Brazil, and as the economic crisis in Brazil deepened, the outflow of Nikkeijin increased exponentially. Instead of viewing the dekasegi experience negatively, as was done in the early 1980s, the Brazilian Nikkeijin began to proclaim this type of migration as a particularly good opportunity for younger Nikkeijin not only to make large sums of money, acquire material goods, and obtain socio-economic mobility, but also as an opportunity to learn the Japanese language, experience true Japanese culture, discover their ancestral roots and acquire useful technical skills whilst they were in Japan. Indeed this positive culture of migration became so entrenched that despite the economic downturn in Japan in the early 1990s, the immigration of Brazilian Nikkeijin into Japan continued. This confirms the postulation that the development of a culture of migration can contribute or significantly expand migrant flow.

The migration flow is generally facilitated by transnational social networks. According to Takeyuki Tsuda these networks link the Nikkeijin with the host country in a number of ways. The networks in this case consist of a highly organized, extensive and efficient transnational labour recruitment and employment system as well as personal networks of Japanese-Brazilians residing in both countries. They are a form of support that expedites and simplifies the migration process. These networks lower the financial and psychological costs and risks of migration, thus making it easier for the Nikkeijin to make the decision to go to Japan. ${ }^{18}$ [Tsuda, 1999] In some cases, the personal networks has attracted Nikkeijin who go to Japan for reasons other than economic ones (e.g. reuniting with family members, marriage, etc.)

What we have learned from the above analysis is that the attempt to understand why international migration occurs requires one to move away from monocausal explanations. As Takeyuki Tsuda argues, one needs to use a "comprehensive migration systems approach" in order to properly come to grips with all of the factors responsible for migration flows among a group of countries. This involves using a dynamic and multi-causal perspective that examines various transnational economic, sociopolitical, and ethnocultural linkages between the sending and receiving countries. [Ibid: 1-3 \& Fawcett, 1989: 672-80] Indeed, Tsuda makes a powerful argument when he suggests that there is now a "culture of migration" in the Japanese-Brazilian sending community in Brazil. This culture of migration coupled with the formation of "transnational migrant networks" between Brazil and Japan constitute part of the historical, ethnic and sociocultural explanation for the increases in volume of these particular migrants. So while economic push-pull factors may be central to this phenomenon, they are not the only ones at play and may not always be 
pivotal (particularly when economic conditions in the host country change as we have seen in the case of Japan).

What is also clear from the above analysis is that over time migration flows can result in the formation of a transnational community of a particular type of sojourners. In the above case it is the transnational community of ethnic Brazilian Nikkeijin. Below I examine another transnational community of Japanese sojourners (Japanese Peruvians) in order to better understand how this type of community developed, how its ethnic identity has been transformed as a consequence of migrations and transnational affiliations, and what impact the migration process itself has had on this particular group of migrants.

\section{The Peruvian Nikkei Community}

Like the Brazilian Nikkeijin, Japanese Peruvians have engaged in what is referred to above as return migration. Japanese Peruvians are "twice migrants" in the sense that most of them were initially from Okinawa, one of the southernmost islands of Japan that was a sovereign nation until it was annexed by the Japanese in 1879. During the turmoil surrounding the demise of the Tokugawa shogunate and its replacement with the new Meiji government, many Okinawans migrated to the Kingdom of Hawaii and the United States. That initial migration flow was followed by a second emigration by 1899 as the US placed stricter controls over its immigration policy with respect to the Japanese. Several of these Okinawan Japanese went to Peru with the temporary intention of making money before returning to Japan. However, the majority of them stayed and Japanese migration to Peru continued at a steady rate until $1923 .{ }^{19}$ [Takenaka, 1999: 1460-61]

The return migration of Japanese Peruvians to Japan followed a similar pattern as that of the Brazilian Nikkeijin. [Table 5] Japan's revision of its immigration laws allowed these Peruvian Nikkeijin to enter Japan with relative ease and to take up employment there. Like the Brazilian Nikkeijin, the Peruvians of Japanese descent faced a grim economic future if they stayed in Peru. Relocating to Japan was made easier because of the abundance of unskilled jobs available to the Nikkeijin, as was noted in the Brazilian case above. It should be noted that several Peruvian Nikkeijin (Particularly those of mixed race), after emigrating to Japan later emigrated to the United States in search of even better opportunities. Many found that the US was much more open to immigrants than Japan had been. Others simply wanted to reunite with relatives who had emigrated from Okinawa to the US prior to World War II. ${ }^{20}$ [Ibid: 1461]

The Japanese-Peruvians community in Peru, while maintaining their ethnicity and distance from the rest of the Peruvian population, became nevertheless highly acculturated. Most of them are Catholics and Spanish monolinguals. That community has been greatly affected in several ways by the return migration. For instance, during the height of the return migration (i.e. 1990-92) close to $40 \%$ of the Peruvian Nikkeijin left Peru for Japan. Most of them were third generation Nikkeijin. This mass exodus had a major impact on the main 
Conceptualizing Transnational Community Formation:

Migrants, Sojourners and Diasporas in a Globalized Era

Table 4

Legally Resident Brazilians in Japan, 1975-1995

\begin{tabular}{cccc}
\hline 1975 & 1985 & 1990 & 1995 \\
\hline 1,418 & 1,955 & 56,429 & 176,440 \\
$0.2 \% *$ & $0.2 \% *$ & $5.2 \% *$ & $13.0 \% *$ \\
\hline
\end{tabular}

* Percentage of total foreign population

Source: Japan, Ministry of Health and Welfare, Latest Demographic Statistics, 1990-1991. Tokyo: Institute of Population Problems, 1991.

Table 5

Legally Resident Peruvians in Japan, 1975-1995

\begin{tabular}{cccc}
\hline 1975 & 1985 & 1990 & 1995 \\
\hline- & 480 & 10,279 & 36,269 \\
$0.0 \% *$ & $0.1 \% *$ & $1.0 \% *$ & $2.7 \% *$ \\
\hline
\end{tabular}

* Percentage of total foreign population

Source: Japan, Ministry of Health and Welfare, Latest Demographic Statistics, 1990-1991. Tokyo: Institute of Population Problems, 1991.

Japanese-Peruvian school, for example, as enrolment declined by 1,600. Indeed, the impact was felt throughout the Japanese-Peruvian community -- e.g. in small businesses that lost many of their employees and in athletic clubs that were almost empty. At the same time, however, the return migration also had some positive effects. Remittances from those who had emigrated brought significant revenues into the community, allowing many Nikkeijin to improve their socio-economic and even political status. We are all well aware of the fact that a Japanese-Peruvian, Alberta Fujimori, became President of Peru. A slew of new Japanese-Peruvian small businesses was opened and has flourished. There 
W. Andy Knight

was a demand for Japanese language courses and a re-connection by the Peruvian Nikkeijin with all things Japanese. As Takenaka put it, even "racially mixed Japanese Peruvians in Peru's rural areas who had no prior consciousness of their Japanese background have suddenly become aware of their heritage and want to 'maintain' Japanese customs." [Ibid: 1464]

All this activity has bolstered the Japanese-Peruvian community in Peru. That community has been transformed from one that had very little connection to the ancestral home to one that is now very self-conscious about its "Japanese-ness". This has further accentuated the ethnic difference between the Nikkei and the rest of the Peruvian population. Nikkei values (traditional Japanese values) are now considered positively by all generations of the Nikkeijin. Indeed many of the traditional values and customs being adhered to by the Japanese Nikkeijin are no longer practiced by contemporary Japanese youth (e.g. mutual help, discipline, respect for the elderly, care for those in the family, honesty, trustworthiness, hard work, responsibility and punctuality). Takenaka explores the factors that contribute to the consolidation of this 'transformed' Japanese-Peruvian community and which have made the Peruvian Nikkei distinct not only from non-Japanese Peruvians but also from Japanese living in Japan. [Ibid: 1461-64] The main point made is that values (rather than blood, per se), culture, tradition and the "symbolic interpretation" of its distant heritage, are the ingredients that hold the Japanese-Peruvian community together.

This community is a transnational community that labels itself a "Nikkei" community - as opposed to a Japanese-Peruvian community or a contemporary Japanese community. In other words, it is a distinct transnational community that has redefined itself based on something other than strictly "blood-based ethnicity". Indeed, the reference point for this Nikkei community is the traditional Japanese values which are believed to be inherited from Japanese ancestry but which no longer exist in Japan. The community is held together not only by the intersubjective consensus over these values but also by strict membership selection criteria, norms and codes of behaviour, written and unwritten rules, and methods of punishment for those who deviate from those norms, codes and rules. [Ibid: 1466]

This Nikkei community has been constructed in Peru. However, it has transcended the state as Japanese-Peruvians become dispersed across the globe. The transnational Nikkei community is linked by an increasing number of transnationally operated Nikkei companies such as remittance firms, by a set of international Nikkei institutions such as the Pan-American Nikkei Association, by a number of annual Nikkei conferences, and by major transborder Nikkei sporting events and associations. "The extended transnational network has reinforced a Nikkei identity among Japanese Peruvians not only in Peru but also in the United States and Japan." [Ibid: 1470-73] As a result, rather than becoming part of a melting pot, Japanese Peruvians have developed a set of symbolic values, norms and codes that operate across national borders to ensure a distinctive Nikkei identity and community. This case study could assist in the development of a theory of transnational community formation among international migrants, who are, for all intents and purposes, sojourners. 
Conceptualizing Transnational Community Formation:

Migrants, Sojourners and Diasporas in a Globalized Era

\section{Diasporas as International Sojourner Communities}

What we have noticed from the two case studies above is that ethnic bonds are primordial, recurrent and sometimes inexplicable. These bonds can have an overpowering emotive quality tying individuals together in a non-rational manner. But, in all cases, ethnic bonds are constructed; i.e. they stem from some social or political project, and are developed over time through socialization as well as through myths and narratives passed on from generation to generation. Ethnies share symbols and myths of origin, which hold them together. Some ethnies have a strong attachment to territory, but others have a strong attachment to an "idea" rather than a piece of land per se. Other ethnies may be more concerned with physical detachment from a territory (at least temporarily) while at the same time having a longing for that place. Diasporas fall into this category.

As noted above, the concept of diaspora is undergoing some revision during the contemporary globalized era. Yet, what holds this concept together is the notion that all diasporas suffer some traumatic event, which leads to dispersal of their members, who, nevertheless, continue to aspire to return to the homeland. Therefore while members of a diaspora are international migrants, diaspora as a concept can be distinguished from that of general international migration.

Diaspora communities identify strongly with their original or ancestral homeland. [Ostergaard-Nielsen, 2002: 4] What separates those in the diaspora community from other migrant populations and ethnic minorities is that those in the diaspora community wish to return home at some point when the situation is better (i.e. when the homeland is safe for their return) and the conditions are right (i.e. when the economic conditions are better, when they can feel free to practice their religion without fear of persecution, or when a repressive regime is no longer in power). Thus, it is not surprising that most members of a diaspora generally will have difficulties assimilating into the host country because they see their current location as little more than a temporary home. [Marienstras, 1989: 120]

Safran who lists six basic characteristics of contemporary diasporas confirms this. These characteristics are: 1) dispersal from an original centre to at least two peripheral places; 2) maintenance of a memory, vision, or myth about their original homeland; 3) belief that they cannot be fully accepted by their host country; 4) longing to return to the ancestral home when the time is right; 5) commitment to the maintenance and/or restoration of the homeland; 6) development/construction of a consciousness and solidarity as a group defined largely around the continued relationship with the homeland. [Safran, 1991: 8384] One can argue, based on the above characterization, that diasporas articulate a cosmopolitanism that is in tension with the nation-state assimilationist ideology. At the same time, it is also in tension with indigenous and autochthonous claims. 
Toloyan has observed that "diasporas constitute the exemplary communities of the transnational moment." [Toloyan, 1991: 5] Indeed, diasporas not only draw considerable strength from transnational processes; they also contribute (sometimes unwittingly) to the intensification of those processes by their own activity. [Ostergaard-Nielsen, 2002] Diaspora in one country may mobilize on behalf of national or religious compatriots residing in another country. For instance, Turkish Sunni-muslims in Germany collected funds to support muslims in Bosnia and Kosovo. Another example of this kind of transnational diasporic activity can be found in the Ocalan case. After Ocalan's capture, Kurds in several countries orchestrated simultaneous protests in a number of different countries, using fax machines, mobile phone and the mass media to maximum effect.

Yet, surprisingly, many ethnic diasporic communities are not strong advocates of transnationalism. Instead, some of them are more interested in nationalist projects that would bring space and identity together in their respective homelands (states). Some observers have called this "long distance nationalism". This diasporic goal of re-territorialization may seem at odds with the globalization effect of de-territorialization. However, the transnational character of all diaspora groups is clearly fed by the globalization phenomenon.

\section{Conclusions}

The growing interest in international migration is directly linked to the phenomenon of globalization and its concomitant trend, globalism. Globalization and globalism have resulted in the shrinking of time and space. The world is indeed becoming a global village in many respects. However, as conditions in this globalized era make it easier for people to travel in search of better jobs, a better life and freedom from fear, certain governments (mostly in the developed world) are concerned that international migration could upset the delicate political and socio-economic balance that currently prevails among their populations. Some other governments (mostly in the developing world) are concerned that international migration could further impoverish them. Yet, others also in the developing world rely heavily on international migration for remittances (e.g. the Philippines). Thus, policies are being developed to curb immigration and emigration, in some cases, while at the same time to encourage certain types of international migration. It would seem that, in light of the fact that international migration is an under-theorized concept, the time may be ripe for a deepening of our understanding of what causes international migration and what are its impacts in a globalized era.

The foregoing analysis is designed to provide fodder for such theorization. As shown earlier, single causal analysis gives us only a limited understanding of the nature and impact of international migration. A multi-variate analysis of transnational community formation that combines the explanations of rational choice economics theory at both macro and micro levels, the new economics of 
Conceptualizing Transnational Community Formation:

Migrants, Sojourners and Diasporas in a Globalized Era

migration theory, dual labour market theory, and network theory with the characterization of various variants of international migration should bring us closer to developing a comprehensive and holistic theoretical framework within which to study this phenomenon.

\section{Acknowledgements:}

The author wishes to thank Yasmeen Abu Laban for her comments on a previous draft, and Solanna Anderson for her research assistance.

\section{End Notes:}

1. Note that according to the United Nations High Commissioner on Refugees (UNHCR) there were an estimated 21,793,300 refugees and displaced persons across the globe. See http://www.unhcr.ch/cgibin/text/vtx/home?page=basics

\section{See http://www.unhcr.ch/statist/main.htm}

3. Note that a number of international meetings brought attention to the issue, e.g. the International Conference on Population held in Mexico in 1984.

4. See the Report of the International Conference on Population and Development, Cairo, 5-13 September 1994 (United Nations Publication, E.95. XIII.18), especially chapter 1, resolution 1, annex.

5. Globalism and globalization processes result in the shrinkage of social, political, economic, and cultural distances. As a consequence of these phenomena, formerly dense and opaque frontiers are being dissolved and national boundaries are becoming more porous. However, for conceptual purposes, globalization and globalism can be distinguished. The former refers to the ongoing economic restructuring at the global level, propelled by the process of trade liberalization (and a hyper-liberal ideology) and leading to rapid acceleration of global economic integration. The latter is a broader term that embraces 'globalization' but also indicates a sociocultural, political and economic process that could ultimately lead to the development of a sense of global citizenship among peoples of the globe.

6. Such conflicts proliferated among ethnic groups in places like Azerbaijan, Armenia, Bhutan, the Caucasus, the Great Lakes region of Africa, Iraq, Liberia, Myanmar, Sierra Leone, Somalia, Sri Lanka, the Sudan, and the former Yugoslavia.

7. John Rex, "The Nature of Ethnicity in the Project of Migration," in Montserrat Guiberneau \& John Rex (eds.), The Ethnicity Reader: Nationalism, Multiculturalism and Migration, p.269. 
8. This immediate post Cold War period also coincides with what appears to be a decline in interest in the political ideal of multiculturalism. This is particularly noticeable in Canada.

9. Examples of the latter policies would include such measures as employer sanctions, immigration quotas, etc.

10. For further elaboration see Douglas Massey et. al., "Migration theory, ethnic mobilization and globalization," in Montserrat Guiberneau \& John Rex (eds.), The Ethnicity Reader: Nationalism, Multiculturalism and Migration, pp.259-261.

11. It is important to note, however, that there are a host of issues around how "family" is defined in receiving states.

12. Postmodernist academics are especially guilty of overusing and misappropriating the term.

13. One could argue, of course, that once the state of Israel was proclaimed in 1948, in essence the Jewish diaspora (in the classic sense of the term) disappeared.

14. Some states turn a blind eye to the problem, when convenient, since "illegal migrants" may be wanted by exploitative businesses operating in those states.

15. Note that in 1988 the number of Brazilian nikkeijin was 4,159 .

16. Note that Japan changed its immigration laws in 1990 by revising the Immigration Control and Refugee Recognition Act that legally admitted the Nikkeijin without restriction, up to the third-generation Sansei.

17. One should note that during the mid- to late 1908s, Japan was also faced with a rash of illegal immigrant from a number of Asian countries whose cultural and language were quite different from the Japanese. The Japanese were very uncomfortable with this situation and this made it easier for them to accept migrant workers who were of the same ethnic background and who were familiar with the Japanese language.

18. For a full elaboration of the ways in which these networks operate, see Takeyuki Tsuda, "The Motivation to Migrate: The Ethnic and Sociocultural Constitution of the Japanese-Brazilian Return-Migration System," Economic Development and Cultural Change vol.48 (1) Oct 1999.

19. That was the year when Japanese migration to Peru by contract was terminated. See http://camel2.conncoll.edu/academics/departments/transnat/history/pbhist.ht $\underline{\mathrm{ml}}$ 
Conceptualizing Transnational Community Formation:

Migrants, Sojourners and Diasporas in a Globalized Era

20. According to Takenaka, of the 80,000 to 90,000 Japanese-Peruvians today, one third live in Japan as contract workers and the remainder reside either in the US or Peru.

\section{References:}

Abu-Laban, Yasmeen. 1997. "Collapsing the Boundaries between 'Foreign' and 'Domestic': Re-thinking Multiculturalism and Immigration Policies on the Eve of the Twenty-First Century," paper presented at the Thirteenth Annual Political Science Students' Conference on "Between East and West: Atlantic and Pacific Dimensions of Canadian Foreign Policy", The Centre for Defence and Security Studies, University of Manitoba. (January 30- February 1).

Appadurai, Arjun. 1999. "Dead Certainty: Ethnic Violence in the Era of Globalization," in Birgit Meyer \& Peter Geschiere (eds.) Globalization and Identity: Dialectics of Flow and Closure. Oxford: Blackwell Publishers.

Appadurai, Arjun. 1990. "Disjuncture and Difference in the Global Cultural Economy," in M. Featherstone (ed.), Global Culture: Nationalism, Globalization and Modernity. London: Sage.

Bagchi, Ann D. 2001. "Migrant networks and the immigrant professional: An analysis of the role of weak ties," Population Research and Policy Review, vol.20, no 1-2.

Castles, Stephen \& Mark J. Miller. 1993. The Age of Migration: International Population Movements in the Modern World. London: Macmillan.

Clifford, James. 1997. "Diaspora", in Montserrat Guibernau \& John Rex (eds.), The Ethnicity Reader: Nationalism, Multiculturalism and Migration. Cambridge: Polity Press.

Cornelius, Wayne A. 1994. "Japan: The Illusion of Immigration Control," in Wayne Cornelius, Philip L. Martin and James F. Hollifield (eds.), Controlling Immigration: A Global Perspective. Stanford, California: Stanford University Press.

Elazar, D. J. 1986. "The Jewish People as the Classic Diaspora: A Political Analysis," in G. Sheffer (ed.), Modern Diasporas in International Politics. London: Croom Helm.

Encyclopaedia Judaica. 1971. vol. 6. Jerusalem. 
W. Andy Knight

Fawcett, James T. 1989. "Networks, linkages, and migration systems," International Migration Review 23.

Gmelch, George. 1980. "Return Migration," Annual Review of Anthropology 9.

"Growing illegal immigrant numbers beg tough question", Edmonton Journal, May 27, 2001.

Harris, J. R. \& Michael Todaro. 1970. "Migration, unemployment, and development: a two sector model," American Economic Review, no. 60.

Held, David, Anthony McGrew, David Goldblatt \& Jonathan Perraton. 1999. Global Transformations: Politics, Economics and Culture. Stanford: Stanford University Press.

Helleiner, Gerald K. 2001. "Markets, Politics, and Globalization: Can the Global Economy be Civilized?" Global Governance, vol.7 (3) JulySeptember.

Keohane, Robert \& Joseph Nye (eds.). 1971. Transnational Relations and World Politics. Cambridge: Harvard University Press.

Kritz, Mary M. \& Hania Zlotnik. 1992. "Global Interactions: Migration Systems, Processes, and Policies," in Mary M. Kritz, Lin Lean Lim and Hania Zlotnik (eds.), International Migration Systems: A Global Approach. New York: Oxford University Press.

Lee, Everett. 1966. "A theory of migration," Demography, vol.3, no.1.

Marienstras, R. 1989. "On the Notion of Diaspora," in G. Chaliand (ed.), Minority Peoples in the Age of Nation-states. London: Pluto Press.

Massey, Douglas, et. al. 1994. "International migration theory: the North American case," Population and Development Review, vol.20, no.4.

Massey, Douglas et. al. 1997. "Migration theory, ethnic mobilization and globalization," in Montserrat Guiberneau \& John Rex (eds.), The Ethnicity Reader: Nationalism, Multiculturalism and Migration. Cambridge: Polity Press.

Mittelman, James (ed.). 1997. Globalization: Critical Reflections. Colorado: Lynne Rienner.

Ostergaard-Nielsen, Eva. 2002. "Diaspora in World Politics," in Daphne Josselin \& William Wallace, Non-State Actors in World Politics. Palgrave/Macmillan Press. 
Conceptualizing Transnational Community Formation:

Migrants, Sojourners and Diasporas in a Globalized Era

Piore, Michael. 1979. Birds of Passage: Migrant Labour in Industrial Societies. Cambridge: Cambridge University Press.

Reichl, Christopher A. 1995. "Stages in the historical process of ethnicity: The Japanese in Brazil, 1908-1988," Ethnohistory 42.

Rex, John. 1997. "The Nature of Ethnicity in the Project of Migration," in Montserrat Guiberneau \& John Rex (eds.), The Ethnicity Reader: Nationalism, Multiculturalism and Migration. Cambridge: Polity Press.

Safran, William. 1991. "Diaspora in modern societies: Myths of homeland and return," Diaspora 1 (1).

Sellek, Yoko. 1996. "The U-Turn Phenomenon among South AmericanJapanese Descendants: From Emigrants to Migrants," Immigrants and Minorities 15.

Sjaastad, Larry. 1962. "The costs and returns of human migration," Journal of Political Economy, no.705.

Takenaka Ayumi. 1999. "Transnational community and its ethnic consequences: The return migration and the transformation of Japanese Peruvians," American Behavioral Scientist Vol.42 (9) June/July.

The Blackwell Companion to Jewish Culture: From the Eighteenth Century to the Present. 1989, edited by Glenda Abramson. Oxford: Basil Blackwell Ltd.

Todaro, Michael. 1976. Internal Migration in Developing Countries. Geneva: International Labour Office.

Toloyan, K. 1991. "The nation-state and others: In lieu of a preface," Diaspora: A Journal of Transnational Relations, vol.1, no.1.

Tsuda, Takeyuki. 1999. "The motivation to migrate: The ethnic and sociocultural constitution of the Japanese-Brazilian return-migration System," Economic Development and Cultural Change vol.48 (1) October.

United Nations. Department of Economic and Social Affairs, Population Division. 1998. World Population Monitoring, 1997: International Migration and Development. New York: United Nations.

UNHCR. May 2001. 2000 Global Refugee Trends. Geneva: United Nations.

Vertovec, Steven. 1997. "Three meanings of 'Diaspora', exemplified among South Asian religions," Diaspora, vol.6, no.3 (Winter). 
W. Andy Knight

Wallerstein, Immanuel. 1974. The Modern World System: Capitalist

Agriculture and the Origins of the European World-Economy in the Sixteenth Century. New York: Academic Press.

Received July 2001; Revised February 2002 
Conceptualizing Transnational Community Formation: Migrants, Sojourners and Diasporas in a Globalized Era

${ }^{1}$ Note that according to the United Nations High Commissioner on Refugees (UNHCR) there were an estimated 21,793,300 refugees and displaced persons across the globe. See http://www.unhcr.ch/cgi-bin/text/vtx/home?page=basics

${ }^{2}$ See http://www.unhcr.ch/statist/main.htm

${ }^{3}$ Note that a number of international meetings brought attention to the issue, e.g. the International Conference on Population held in Mexico in 1984.

${ }^{4}$ See the Report of the International Conference on Population and Development, Cairo, 5-13 September 1994 (United Nations Publication, E.95. XIII.18), especially chapter 1, resolution 1, annex.

${ }^{5}$ Globalism and globalization processes result in the shrinkage of social, political, economic, and cultural distances. As a consequence of these phenomena, formerly dense and opaque frontiers are being dissolved and national boundaries are becoming more porous. However, for conceptual purposes, globalization and globalism can be distinguished. The former refers to the ongoing economic restructuring at the global level, propelled by the process of trade liberalization (and a hyper-liberal ideology) and leading to rapid acceleration of global economic integration. The latter is a broader term that embraces 'globalization' but also indicates a sociocultural, political and economic process that could ultimately lead to the development of a sense of global citizenship among peoples of the globe.

${ }^{6}$ Such conflicts proliferated among ethnic groups in places like Azerbaijan, Armenia, Bhutan, the Caucasus, the Great Lakes region of Africa, Iraq, Liberia, Myanmar, Sierra Leone, Somalia, Sri Lanka, 
the Sudan, and the former Yugoslavia.

${ }^{7}$ John Rex, "The Nature of Ethnicity in the Project of Migration," in Montserrat Guiberneau \& John Rex (eds.), The Ethnicity Reader: Nationalism, Multiculturalism and Migration, p.269.

${ }^{8}$ This immediate post Cold War period also coincides with what appears to be a decline in interest in the political ideal of multiculturalism. This is particularly noticeable in Canada.

${ }^{9}$ Examples of the latter policies would include such measures as employer sanctions, immigration quotas, etc.

${ }^{10}$ For further elaboration see Douglas Massey et. al., "Migration theory, ethnic mobilization and globalization," in Montserrat Guiberneau \& John Rex (eds.), The Ethnicity Reader: Nationalism, Multiculturalism and Migration, pp.259-261.

${ }^{11}$ It is important to note, however, that there are a host of issues around how "family" is defined in receiving states.

${ }^{12}$ Postmodernist academics are especially guilty of overusing and misappropriating the term.

${ }^{13}$ One could argue, of course, that once the state of Israel was proclaimed in 1948, in essence the Jewish diaspora (in the classic sense of the term) disappeared.

${ }^{14}$ Some states turn a blind eye to the problem, when convenient, since "illegal migrants" may be wanted by exploitative businesses operating in those states.

${ }^{15}$ Note that in 1988 the number of Brazilian nikkeijin was 4,159.

${ }^{16}$ Note that Japan changed its immigration laws in 1990 by revising the Immigration Control and Refugee Recognition Act that legally admitted the Nikkeijin without restriction, up to the thirdgeneration Sansei.

${ }^{17}$ One should note that during the mid- to late 1908s, Japan was also faced with a rash of illegal immigrant from a number of Asian countries whose cultural and language were quite different from the Japanese. The Japanese were very uncomfortable with this situation and this made it easier for them to accept migrant workers who were of the same ethnic background and who were familiar with the Japanese language. 
Conceptualizing Transnational Community Formation: Migrants, Sojourners and Diasporas in a Globalized Era

${ }^{18}$ For a full elaboration of the ways in which these networks operate, see Takeyuki Tsuda, "The Motivation to Migrate: The Ethnic and Sociocultural Constitution of the Japanese-Brazilian Return-Migration System," Economic Development and Cultural Change vol.48 (1) Oct 1999.

${ }^{19}$ That was the year when Japanese migration to Peru by contract was terminated. See http://camel2.conncoll.edu/academics/departments/transnat/history/ pbhist.html

${ }^{20}$ According to Takenaka, of the 80,000 to 90,000 JapanesePeruvians today, one third live in Japan as contract workers and the remainder reside either in the US or Peru. 